\title{
Time Management in Academic Libraries
}

\section{Helen M. Gothberg and Donald E. Riggs}

The study's purpose was to evaluate time management practices among directors of large academic libraries. The 159 respondents to the survey provided information about their time, indicated to what degree they delegated authority, ranked their top ten time wasters, and responded to a section on leadership style. Data analysis and interpretation provided a basis for evaluating the training of library managers, determining the need for additional research in the field, comparing the responses of directors to one another, and showing prospective directors how existing management allocates time.

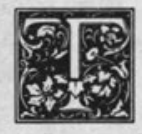

oday's library managers are working under pressures that are unique to this period of time in our institutional and national development. Writers such as Alvin Toffler and John Naisbitt have made us aware of our change from an industrial nation to an information society. ${ }^{1}$ The roles of all institutions are in the process of change. Library directors, especially those who direct large institutions, must ask themselves how the library will be managed to move forward with these changes.

New technologies are available to assist in providing better control over information and are rapidly being adapted to library services and operations. The cost is high and it has come at a time when library budgets are considerably leaner than they were. If the challenges of this new information society are to be met head-on, personnel costs must be reduced. Along with the new technological timesaving devices, both staff and management must become more productive. One road to increased productivity is through efficient time management.

A significant body of business literature on the subject of time management is available. This literature agrees considerably as to what methods constitute effective time management and as to what events and activities can be characterized as the greatest "time wasters."

Experts on the subject of time management such as Alec MacKenzie and Alan Lakein reported that many managers never felt they had enough time to get everything done. ${ }^{2}$ Yet everyone has the same amount of time $-8,760$ hours a year. It's not that some people have more time than others; it's that they know how to manage their time better through efficient management practices.

Managers set a standard for other employees in the library to follow. The results of a study conducted by a large consulting firm showed that the average American worker wasted 45 percent of the day. Wasting time was not always done consciously, but according to the authors, when a worker wasted time, it was "time theft," pure and simple. The cost to American industry was billions of dollars every year. ${ }^{3}$ Efficient time management is not only important for managers in get-

Helen M. Gothberg is Associate Professor, Graduate Library School, University of Arizona, Tucson, Arizona 85719. Donald E. Riggs is University Librarian, Arizona State University, Tempe, Arizona 85287.

Contact Gothberg for additional information regarding this study. The Final Report appears in ERIC 267802. 
ting their own work done, but it also has an effect on those who look to managers as role models.

\section{UTILITY OF THE RESEARCH RESULTS}

Little has been written on the subject of time management in the library profession. Most articles on the subject have dealt with work flow, or time and motion studies of library operations, and have been more concerned with staff than with management. ${ }^{4}$ This lack of interest in library management indicates that, until recently, the largely service oriented and tax supported institutions have felt less urgency about the subject than the profit oriented organizations. Library efficiency and time management practices are interdependent factors, and the need for efficiency in the management of large library collections seems obvious. Are library managers listening, reading, and applying time management techniques? Have library directors learned to work smarter, not harder? These are some of the questions that this study attempted to answer.

\section{Goals and Objectives of the Study}

Three goals were identified for the study. They were as follows:

Goal 1: The primary goal of the study was to collect data related to time management practices and attitudes of library directors in large academic libraries.

Goal 2: The second goal was to analyze and interpret the data in order to provide recommendations for future consideration by library directors and to provide a basis for inservice training of personnel.

Goal 3. The final goal was to report the results to both the participants in the study and to library and other media professionals.

Four objectives of the study were designed to determine:

1. To what degree library managers were aware of and practice efficient time management methods, including delegation of authority and leadership style.

2. Time management practices as related to leadership style, sex of manager, number of people managed, and years of experience as a library director.
3. Identification of the most serious time wasters in library management.

4. How library directors reportedly spent their time based on twelve specified categories.

\section{Sampling and the Plan of the Study}

The overall plan of the study involved the development and use of a mailed questionnaire dealing with time management. The population surveyed consisted of the 105 directors who manage libraries that are members of the Association of Research Libraries (ARL) and 89 libraries that are not ARL members but are listed in the University Library Statistics of Academic, College and Research Libraries as being the largest non-ARL libraries located in doctorate granting institutions.

The total of academic library directors came to 194 . A $60 \%$ return was considered desirable for a reliable sample. To ensure an adequate return of the survey instrument, two mailings were planned and carried out. The final number of returned questionnaires was 159 , or $82 \%$.

\section{Data Collection}

Items used to collect the data in the mailed survey were based on the time management literature. They fell into five categories: (1) a profile of the respondents, (2) how a manager's time is reportedly spent, (3) delegation of authority, (4) time wasters, and (5) leadership style. All items were designed with the assistance of Lawrence M. Aleamoni, the Director of the Office of Instructional Research and Development (IRAD), University of Arizona.

Section I of the survey instrument dealt with a profile of the respondents. Using a four-point interval scale, except for the items that involved gender identification, it collected data about the library directors in the following areas:

A. Size of library staff

B. Number of years in current position

C. Number of years as a library director

D. Number of years as a library administrator (dept. head, etc.)

E. Age

F. Gender 
Section II of the survey instrument used a six-point interval scale to determine the number of hours per week the respondents spent doing the following activities:
A. Planning
B. Reporting
C. Supervising
D. Budgeting
E. Personnel work
F. Meetings with university administra- tors

G. Meetings with library administrators

H. Library committees

I. University committees

J. External fund raising

In addition, a four-point interval scale was used in this section to determine the number of days spent attending off-campus professional meetings or other workrelated events.

\section{"The ability to delegate work is fre- quently mentioned in the literature on leadership as a key element in managing time effectively."}

Section III covered the principle of delegation of authority. The ability to delegate work is frequently mentioned in the literature on leadership as a key element in managing time effectively. Merrill Douglass and Donna Douglass observed that, in spite of the obvious benefits and good sense that delegation makes, many managers are ineffective delegators. They devised a self-quiz to help an individual determine the quality of his/her delegation skills. ${ }^{5}$ Eleven of their sixteen questionnaire items were used in this section. Rather than the yes/no response that was useful in the Douglass self-evaluation instrument, a four-point Likert type scale was devised using the following descriptors to respond to the statements: Agree Strongly (AS), Agree Moderately (A), Disagree Moderately (D), and Disagree Strongly (DS).

Section IV of the survey instrument was on time wasters. The business literature agrees considerably on what wastes a manager's time. Both the Douglasses and Michael LeBoeuf asked managers to list or rank the worst time wasters. ${ }^{6}$ LeBoeuf's fifteen items, based on the work of time expert MacKenzie, were used in this section of the library survey.

In the LeBoeuf study, sales representatives and engineering managers in fourteen countries were asked to rank their top ten time wasters from a list of 15 . For purposes of the academic library study under discussion, library managers were asked to do the same. The reason for collecting this data was to determine whether library managers had the same perspective of what wastes time as either sales representatives or engineering managers. Fifty percent of the mailed surveys were constructed such that the order of the items in this section were reversed to avoid respondent proclivity to select those items at the top of the list.

Section V, the last section of the survey, dealt with leadership. One way to discuss an individual's leadership style is to determine whether a person is primarily concerned with getting the work done-a task leader-or primarily concerned with looking after people and their feelings-a process leader. Douglas McGregor is well known for his classic work on leadership style that described these two sets of contrasting leadership behaviors as "Theory $\mathrm{X}^{\prime \prime}$ and "Theory Y."7 Robert Blake and Jane Mouton integrated the research of McGregor and other industrial psychologists into an easily understood tool for analyzing leadership style along the taskprocess continuum they called the "Managerial Grid." ${ }^{8}$ The four corners of the grid represent four leadership positions:

A. A primary concern for people

B. A primary concern for task

C. A lack of concern for either task or people (the least desirable position on the grid for effective management)

D. A high concern for both task and people (the most productive type of leadership style)

A fifth point on the grid is at the midpoint. This type of leadership has been described as a balancing act between task and people or a country club style of management 
where the leader seems to be task oriented in the morning and people oriented in the afternoon.

Time management concepts that are useful in the business world may seem on the surface to be more task than people oriented, whereas public service organizations may have a greater stake in people or process skills. Recent best-sellers in the management field, such as The One Minute Manager and In Search of Excellence, have stressed the team approach. Their authors concluded that the most effective manager is the one who can combine both task and people skills for the good of the organization. ${ }^{9}$ For this reason, it was important to collect data on library managers' leadership styles. To do this, a short form of the longer, original questionnaire by Blake and Mouton was used. This five-item instrument ranks five statements based on how a manager handles conflict. Respondents to the library survey were placed on the managerial grid according to how the majority rank ordered these statements.

A pretest of the survey instrument was carried out using a sample of twelve $(n=12)$. The only major change in the survey instrument following this pretest was to explain more clearly how the leadership section of the survey fit in with a study of time management, so that respondents would not be reluctant to answer Section V.

\section{Data Analysis}

The SPSS statistical package was used to analyze the data collected in the time management survey of academic library directors. Five analyses were calculated for the data. The first, frequency analysis, tabulated how many responses were in any one category. The results, reported later in this chapter, are in terms of percentiles. Second, the Pearson productmoment correlation was calculated across all the variables in the study. Correlation characterizes the relationship between or among variables, i.e., the degree to which any two variables vary together (positive correlation) or vary inversely (negative correlation). A correlation coefficient indexes two properties of a relationshipthe magnitude of the relationship and the direction of the relationship. It says nothing, however, about the reasons that determine such relationships.

The third analysis carried out on the data from the survey was crosstabs, using chi-square, a subprogram available in SPSS. Chi-square tests for independence between variables. In this study it was used to determine if respondent characteristics in Section I and the variables in Sections II and III of the survey instrument were associated. Variables in these two sections included the number of hours library directors spent on various management activities and responses to statements about delegating authority. Library director rankings of time wasters were compared to those of sales personnel and engineering managers in the LeBeouf study, using rank correlation.

\section{Results}

Section I of the survey instrument dealt with a profile of the library directors returning the questionaire. Some characteristics of the population were as follows: the largest number of respondents, almost $90 \%$, administered staffs of 300 or less, with nearly $58 \%$ administering library staffs of 150 or less. The largest percentage of directors $(46.5 \%)$ had been in their current position five years or less; $38 \%$ had been a library director less than five years-but, on the other hand, nearly $28 \%$ had 16 years or more experience. A large number $(65 \%)$ had served as a library administrator, such as a department head or assistant/associate director, prior to becoming head of a large academic library. Only $6 \%$ had five years experience or less, which would tend to confirm that the path to top management positions in large academic libraries lies through increasing responsibility in leadership roles. Most of the respondents ( $48 \%$ ) fell into the $46-55$ age category, with almost none under the age of 35 . Twenty-one percent were female, a larger percentage than had been anticipated. Although there are more women in top university library management positions than in the past, their numbers continue to remain small (see table 1).

Section II of the survey (table 2) dealt 
TABLE 1

UNIVERSITY LIBRARY DIRECTOR PROFILE

\begin{tabular}{|c|c|c|c|c|}
\hline $\begin{array}{l}\text { Size of library staff } \\
\text { Percent: }\end{array}$ & $\begin{array}{r}1-150 \\
57.9\end{array}$ & $\begin{array}{r}151-300 \\
31.4\end{array}$ & $\begin{array}{r}301-450 \\
7.5\end{array}$ & $\begin{array}{r}451+ \\
3.1\end{array}$ \\
\hline $\begin{array}{l}\text { Number of years in } \\
\text { current position } \\
\text { Percent: }\end{array}$ & $\begin{array}{r}1-5 \\
46.5\end{array}$ & $\begin{array}{r}6-10 \\
25.2\end{array}$ & $\begin{array}{r}11-15 \\
15.7\end{array}$ & $\begin{array}{l}16+ \\
22.6\end{array}$ \\
\hline $\begin{array}{l}\text { Number of years as } \\
\text { a library director } \\
\text { Percent: }\end{array}$ & $\begin{array}{r}1-5 \\
38\end{array}$ & $\begin{array}{r}6-10 \\
17.7\end{array}$ & $\begin{array}{r}11-15 \\
16.5\end{array}$ & $\begin{array}{l}16+ \\
27.8\end{array}$ \\
\hline $\begin{array}{l}\text { Number of years as a } \\
\text { library administrator } \\
\text { Percent: }\end{array}$ & $\begin{array}{l}1-5 \\
6.3\end{array}$ & $\begin{array}{l}6-10 \\
12.6\end{array}$ & $\begin{array}{r}11-15 \\
16.4\end{array}$ & $\begin{array}{l}16+ \\
64.8\end{array}$ \\
\hline $\begin{array}{l}\text { Age } \\
\text { Percent: }\end{array}$ & $\begin{array}{r}23-35 \\
.6\end{array}$ & $\begin{array}{r}36-45 \\
22.6\end{array}$ & $\begin{array}{r}46-55 \\
47.8\end{array}$ & $\begin{array}{l}56+ \\
28.9\end{array}$ \\
\hline $\begin{array}{l}\text { Gender } \\
\text { Percent: }\end{array}$ & $\begin{array}{l}\text { Male } \\
78.6\end{array}$ & & $\begin{array}{r}\text { Female } \\
21.4\end{array}$ & \\
\hline
\end{tabular}

TABLE 2

PERCENT OF TIME SPENT ON MANAGEMENT ACTIVITIES

\begin{tabular}{|c|c|c|c|c|c|c|}
\hline Hours per week: & $0-3$ & 4-7 & $8-11$ & $12-15$ & $16-19$ & $20+$ \\
\hline Planning & 18.2 & 46.1 & 22.1 & 11.7 & 1.3 & .6 \\
\hline $\begin{array}{l}\text { Reporting (internal and external } \\
\text { communications) }\end{array}$ & 18.5 & 48.4 & 22.9 & 7.6 & 2.5 & \\
\hline Supervising & 56.8 & & 10.1 & 1.4 & .7 & .7 \\
\hline Budgeting & 44.8 & 43.5 & 9.1 & 2.6 & 0 & \\
\hline $\begin{array}{l}\text { Personnel work (including collective } \\
\text { bargaining, labor relations) }\end{array}$ & 42.2 & 38.3 & 14.3 & 3.9 & 1.3 & \\
\hline Meetings with university administrators & 49 & 13.9 & 5.1 & 1.9 & 0 & \\
\hline $\begin{array}{l}\text { Meetings with library administrators (e.g., } \\
\text { assistant/associate directors, department heads) }\end{array}$ & 3.9 & 55.5 & 30.3 & 8.4 & 6 & 1.3 \\
\hline Library committees & 63 & 30.5 & 3.9 & 2.6 & 0 & \\
\hline University committees & 67.5 & 27.4 & 3.8 & .6 & .6 & \\
\hline External fund raising & 69.1 & 24.2 & 4.7 & 1.3 & .7 & \\
\hline $\begin{array}{l}\text { Number of days per year off campus for } \\
\text { professional meetings or work related events }\end{array}$ & $0-10$ & $1-20$ & $21-30$ & $30+$ & & \\
\hline Percent & $\overline{4.5}$ & $\overline{41.3}$ & 33.5 & $\overline{20.6}$ & & \\
\hline
\end{tabular}

with the number of hours per week that library directors normally spent in the traditional areas of management. Those areas where the greatest number of respondents spent the least amount of time, i.e., three hours a week or less, were external fund-raising (69\%), university committees $(67.5 \%)$, library committees $(63 \%)$, and supervising $(57 \%)$. In the four- to sevenhour category only one area was indicated by $55 \%$ of the library directors-meetings with library administrators-followed closely by planning ( $46 \%)$ and reporting $(48 \%)$. In examining the eight to eleven hours per week category, the largest number of library directors reported in the ar- eas of meeting with other library administrators $(30 \%)$, reporting $(23 \%)$, and planning (22\%). Twelve percent of those who responded to the survey indicated they spent between twelve and fifteen hours a week doing planning, and $8 \%$ spent this amount of time in the areas of reporting and meetings with library administrators.

Other trends in the data in table 2 are that $88.5 \%$ of the library directors spent seven hours or less doing budgeting. Because budgeting was one of the major time-consuming activities of academic library directors in the past, the impact of automation and the hiring of specialized 
budgeting personnel can be seen in these figures. Meetings and committee work, however, come in for a large share of administrative time. Although $57 \%$ of the respondents spent three hours or less per week doing any supervision, $30 \%$ indicated they spent from four to seven hours a week. Finally, $41 \%$ spent between 11 and 20 days a year off campus attending professional meetings or other workrelated events, and $33.5 \%$ spent between 21 and 30 days a year. Nearly $21 \%$ of them spent over 31 days, or more than a month, away from the library doing other types of professional work. Presumably, much of this additional time involves meetings and other types of committee work.

\section{"Nearly $21 \%$... . spent over 31 days, or more than a month, away from the library doing other types of profes- sional work."}

In Section III of the survey instrument, library directors indicated their agreement or disagreement with a series of statements regarding their willingness to delegate authority - a significant factor in effi- cient time management (see table 3 ). Positively worded statements were numbered 1, 2, 5, 6, 8, 9, and 11 . Negatively worded items were numbered $3,4,7$, and 10. An effective delegator would agree with the positively worded statements and disagree with the negatively worded ones. A large percent of the library directors $(84-90 \%)$ indicated the appropriate agree/disagree response for effective delegation of authority on all items but two. The two items in question were number one: "I frequently allow my staff to make mistakes," and number three: "I frequently do tasks that my subordinates should be doing." For item number one, involving staff error, $63.5 \%$ of the directors indicated that they agreed either strongly or moderately with this statement. For item number three, which was concerned with doing subordinates' tasks, only $69 \%$ indicated disagreement, a somewhat lower percent than the $85-90 \%$ desired response to the other statements.

Identifying the top ten time wasters was the purpose of collecting data in Section IV. The results were then compared to rankings made by sales representatives and engineering managers in a prior study by Michael LeBoeuf. ${ }^{10}$ The rankings for each occupational group appear in table 4 . Number one is ranked as the item that hin-

TABLE 3

DELEGATION OF AUTHORITY*

\begin{tabular}{|c|c|c|c|c|}
\hline & AS & A & D & DS \\
\hline 1. I frequently allow my staff to make mistakes. & 13.8 & 49.7 & 29.6 & 6.9 \\
\hline $\begin{array}{l}\text { 2. My staft make most of the day-to-day decisions about their } \\
\text { work without my prior approval. }\end{array}$ & 60.1 & 38 & 1.3 & \\
\hline 3. I frequently do tasks that my subordinates should be doing. & 1.3 & 29.7 & 43.7 & 25.3 \\
\hline 4. The library does NOT function smoothly when I am absent. & .6 & 2.5 & 37.1 & 59.7 \\
\hline $\begin{array}{l}\text { 5. I seldom revise decisions made by my staff. } \\
\text { 6. I give my library staff considerable authority over work (e.g., }\end{array}$ & 28.9 & 59.7 & 10.7 & .6 \\
\hline $\begin{array}{l}\text { personnel, finances, facilities, and resources). } \\
\text { 7. Ifrequently make decisions that are part of my subordinates' }\end{array}$ & 44 & 50.9 & 5 & 0 \\
\hline $\begin{array}{l}\text { 8. I delegs. } \\
\text { de most library operations to my staff. }\end{array}$ & ${ }_{42}^{0}$ & 9.5 & 55.1 & 35.4 \\
\hline $\begin{array}{l}\text { 9. If I were incapacitated for six months, there is someone on } \\
\text { my staff who could readily take over my job for that period }\end{array}$ & 72.1 & 8.0 & & .0 \\
\hline 10. The department heads under my leadership & 44.9 & 41.8 & 10.1 & 3.2 \\
\hline $\begin{array}{l}\text { delegate work well to their own subordinates. } \\
\text { 11. My key people take the initiative for projects without }\end{array}$ & 1.3 & 9.2 & 64.7 & 24.8 \\
\hline for me to think of them. & 26.1 & 59.3 & 14.0 & .6 \\
\hline
\end{tabular}

- Percent of academic library directors responding. 
TABLE 4

TOP TEN TIME WASTERS RANKED BY THREE OCCUPATIONAL GROUPS

\begin{tabular}{|c|c|c|c|}
\hline & $\begin{array}{l}\text { Library } \\
\text { Manager }\end{array}$ & $\begin{array}{l}\text { Sales } \\
\text { Reps }\end{array}$ & $\begin{array}{c}\text { Engineering } \\
\text { Managers }\end{array}$ \\
\hline Attempting too much at once and estimating time unrealistically & 1 & 8 & - \\
\hline Cluttered desk and personal disorganization & 2 & - & - \\
\hline Confused responsibility and authority & - & - & - \\
\hline Crises (personal and/or staff) & 5 & 4 & 6 \\
\hline Drop-in visitors & 6 & 2 & 9 \\
\hline Inability to say no & - & - & - \\
\hline Inadequate, inaccurate, or delayed information & 7 & - & 1 \\
\hline Indecision and procrastination & - & 7 & 8 \\
\hline Ineffective delegation and involvement in routine and detail & 9 & - & 2 \\
\hline Lack of objectives, priorities, and deadlines & - & 6 & - \\
\hline Lack of, or unclear, communications or instructions & 4 & 10 & 5 \\
\hline Lack of self-discipline & 10 & 3 & 10 \\
\hline Leaving tasks unfinished & - & $\underline{9}$ & 7 \\
\hline Meetings (scheduled and unscheduled) & 3 & 5 & 4 \\
\hline Telephone interruptions & 8 & 1 & 3 \\
\hline
\end{tabular}

dered the respondents the most in getting work completed on time and number ten as the item that hindered them the least.

Library managers ranked attempting too much at once and estimating time unrealistically as number one, followed by a cluttered desk and personal disorganization, and third, meetings. All three groups listed meetings in the top half of those activities that wasted their time the most. Engineering managers did not list attempting too much among the top ten time wasters, and sales representatives placed it near the bottom of the list. Neither sales nor engineering personnel listed cluttered desk as a problem. All three groups omitted confused responsibility and authority and inability to say no from their rankings. Library managers had far less problem with inadequate information than engineers, who ranked it as number one. Both groups of managers listed problems with communication as number ten. Both groups of managers found few problems with self-discipline, while sales people ranked it number three. Leaving tasks unfinished was not ranked among library managers and was low for both sales reps and engineering managers. On the other hand, telephone interruptions, which were ranked number eight for library managers, were number one for sales personnel and number three for engineering managers.

There are some differences between the two management groups. For example, li- brary managers have better control over the telephone probably because they have well-trained support staff. Library managers also perceived themselves as having fewer problems with delegation of work and having better access to information. However, there are more similarities than differences, which is borne out statistically by a low positive relationship between the two groups of managers with a correlation of .3045. On the other hand, a very low negative correlation of -.1755 was found between library managers and sales representatives. These results may say something about the nature of the work itself, or they may say something about the skills needed to succeed in management. Certainly library managers need to be concerned with their top three time wasters.

Much has been written about leadership style over the years. In the beginning there was an effort to identify the traits of a leader. Later researchers in the field of industrial psychology believed that leaders were either process, i.e., people oriented, or they were task oriented. Today there is a trend toward team leadership, incorporating both aspects of leadership-task and process.

Section $\mathrm{V}$ of the survey provided data about the leadership style of the respondents based on how they dealt with conflict (see table 5). Although a task leader may get more work out of subordinates, eventually revenge psychology sets in and 


\section{TABLE 5}

\section{LEADERSHIP STYLE}

\begin{tabular}{ll}
\hline \hline Rank & \multicolumn{1}{c}{ Conflict Statement } \\
\hline 5 & When conflict arises, I try to identify reasons for it and seek to resolve underlying causes. $(9,9)$ \\
4 & When conflict arises, I try to find a compromise that everyone will be satisfied with. $(5,5)$ \\
3 & When conflict arises, I try to remain neutral. $(1,1)$ \\
2 & $\begin{array}{l}\text { I avoid causing conflict, but when it does appear, I try to smooth things over so everyone will } \\
\text { be happy. }(1,9)\end{array}$ \\
1 & When conflict arises, I try to cut it off or win my position. $(9,1)$ \\
\hline
\end{tabular}

the creative thinking necessary in today's organization is lost. Yet a manager who is people oriented at the expense of task will have a less productive staff. The library managers were asked to rank five statements from one to five with one being the least typical and five being the most typical. Table 5 shows how these statements were ranked based on a numerical position found on the Managerial Grid-indicated in parentheses.

Blake and Mouton matched the most typical statement with a position on the Managerial Grid, reflecting leadership style as indicated by numbers. Each of the five positions on the grid is explained below:

\section{9,9 Team Management. "Work accom-} plishment is from committed people; interdependence through a 'common stake' in organization purpose leads to relationships of trust and respect."

5,5 Organization Management. "Adequate organization performance is possible through balancing the necessity to get out work with maintaining morale of people at a satisfactory level."

1,1 Impoverished Management. "Exertion of minimum effort to get required work done is appropriate to sustain organization membership."

1,0 People-Centered Management. "Thoughtful attention to needs of people for satisfying relationships leads to a comfortable, friendly organization atmosphere and work tempo."

9,1 Authority-Obedience. "Efficiency in operation results from arranging conditions of work in such a way that human elements interfere to a minimum degree.",11
". . . most of the academic library ad- ministrators selected a team manage- ment approach. ....'

In looking over the results, we find that most of the academic library administrators selected a team management approach as their most typical response. This ranking was followed in order by a middle position which, although satisfactory, has also been characterized as a country club style of leadership-task oriented in the morning and process oriented in the afternoon. The third-ranked selection was one in which the manager shows little interest in either people or task, followed by democratic or people oriented management, with an authoritarian style being the lowest ranked among the greatest number of respondents.

\section{Generalizability}

Information related to the characteristics of the respondents was collected as part of the survey instrument. The degree to which any other group of individuals fits the description of the population surveyed is the degree to which the results of the survey can be generalized.

\section{Limitations of the Study}

The limitations of the study are based on the degree to which respondents were able to report accurately the number of hours they spent on management activities and the degree to which they actually do what they reported when it comes to the delegation of authority and leadership 
style. Given the level of maturity and responsibility of the population surveyed for this study, it is reasonable to believe that discrepancies, if any, are not so great as to affect seriously the outcome of the study.

\section{Suggestions for Further Research}

One of the purposes of the investigation was to generate a body of data that would form the basis for continued study and research. Additional study into the area of time management in academic libraries should involve a more in-depth examination of exactly how academic library directors use their time, the degree to which they delegate authority, and their leadership style based on actual observation. Other research might involve the effects of changing time management practices, delegation patterns, and/or leadership style. The effects of training decisionmaking groups in group dynamics have been studied under other conditions, but its effectiveness could also be investigated in the academic library. ${ }^{12}$ Alternatives to the traditional committee structure, which preserves or encourages a team approach to management, should be explored. Finally, a replication of this study with other groups of library directors such as those in public libraries or community colleges and other smaller academic institutions may also prove useful.

\section{"If you have enough meetings over a long period of time, the meetings be- come more important than the prob- lems that the meetings were intended to solve."}

\section{SUMMARY}

The results of data analysis for this study imply that the academic library directors who responded to this questionnaire are experienced and mature individuals. They are knowledgeable about appropriate delegation skills and are, for the most part, team management oriented in their leadership styles. Their top three time wasters helped focus on areas in need of attention. The first concern is the need to examine the amount of time spent on committee work. As organizational structure continues to evolve, new ways of dealing with decision making and work flow, other than by committee, should be considered for greater productivity while not falling back on an outmoded authoritarian leadership style.

Secondly, the problem of taking on too much work should be addressed. This problem could be resolved by more effective delegation; however, given the results of the study, it may have more to do with identifying goals and establishing priorities. For example, utilizing time management techniques could resolve the problem of the cluttered desk. Both of these latter time wasters are perceived as more likely to occur in a bureaucratic organization such as the university and may be the inevitable result of committee proliferation.

Management by committee has fostered many benefits, but it has generated its own set of problems. Millions of dollars are spent annually in library committee meetings that result in time lost from operational tasks. "If you have enough meetings over a long period of time, the meetings become more important than the problems that the meetings were intended to solve," wrote Thomas Martin in Malice in Blunderland. ${ }^{13}$ Management expert Peter Drucker wrote: "In every human organization there is far too much need for cooperation, coordination, and human relations to have to provide for additional meetings. And the human dynamics of meetings are so complex as to make them very poor tools for getting any work done. ${ }^{\prime 14}$ Academic library directors are probably not in a position to do much about the number of university committee meetings they attend, because these meetings correlate with the number of hours spent in meetings with university administrators. They can, however, tackle the problem of too many library committees. 


\section{REFERENCES}

1. Alvin Toffler, The Third Wave (New York: Bantam, 1981); John Naisbitt, Megatrends, rev. ed. (New York: Warner, 1984).

2. Alec R. MacKenzie, The Time Trap (New York: AMACOM, 1972); Alan Lakein, How to Get Control of Your Time and Your Life (New York: Wyden, 1973).

3. Merrill Douglass and Donna Douglass, "Time Theft," Personnel Administrator 26:13-15 (Sept. 1981).

4. Howard Samuelson, "Increasing Public Library Productivity," Library Journal 106:309-11 (Feb. 1, 1981); William Kozumplik, "Time and Motion Study of Library Operators," Special Libraries 60:585-88 (Oct. 1969); Richard H. Logsdon, "Time and Motion Studies in Libraries," Library Trends 3:401-9 (Jan. 1954); Elsie H. Mauro and David C. Weber, "Time Management for Library Staffs," Journal of Library Administration 1:13-20 (Winter 1980).

5. Merrill Douglass and Donna Douglass, Manage Your Time, Manage Your Work, Manage Yourself (New York: AMACOM, 1980).

6. Ibid.; Michael LeBoeuf, "Managing Time Means Managing Yourself," Business Horizons 23:41-46 (Feb. 1980).

7. Douglas McGregor, The Human Side of Enterprise (New York: McGraw-Hill, 1960).

8. Robert R. Blake and Jane Srygley Mouton, The New Managerial Grid (Houston: Gulf Pub., 1978).

9. Kenneth Blanchard and Spencer Johnson, The One Minute Manager (Escondido, Calif.: BlanchardJohnson, 1981); Thomas J. Peters and Robert N. Waterman, Jr., In Search of Excellence; Lessons from America's Best-Run Companies (New York: Warner, 1982).

10. Michael LeBoeuf, "Managing Time."

11. Robert R. Blake and Jane Srygley Mouton, How to Improve Your Management Style and How the Mangement Grid Can Help (New York: AMACOM, 1979). "The Guide," p.37-41.

12. Jay Hall, "Decision," Psychology Today (1971), p.51-54, 85-88.

13. Thomas Martin, Jr., Malice in Blunderland (New York: Knopf, 1984), p.33.

14. Peter F. Drucker, Management: Tasks, Responsibilities and Practice (New York: Harper, 1974), p.548. 